\title{
Identifikasi Kadar Merkuri pada Depot Air Minum Isi Ulang di Kelurahan Jati Kota Padang
}

\author{
Kirbi Vira Akesa ${ }^{1}$, Julizar ${ }^{2}$, Husnil Kadri $^{3}$
}

\begin{abstract}
Abstrak
Berdasarkan Permenkes No.492/2010 tentang persyaratan kualitas air minum, merkuri merupakan bahan kimia yang berhubungan dengan kesehatan, sehingga kadar maksimum yang diperbolehkan adalah 0,001000 mg/L. Merkuri memiliki efek berbahaya apabila diatas $0,001000 \mathrm{mg} / \mathrm{L}$. Tujuan penelitian ini adalah untuk mengidentifikasi kadar merkuri pada sampel air minum isi ulang di Kelurahan Jati, Padang. Jenis penelitian ini adalah studi deskriptif dengan teknik pengambilan sampel secara total sampling. Populasi dalam penelitian ini adalah seluruh Depot Air Minum Isi Ulang (DAMIU) yang berada di Kelurahan Jati Kecamatan Padang Timur Kota Padang yaitu sebanyak 15 buah. Penelitian ini dilaksanakan dari Agustus 2017 sampai Februari 2018. Penetapan kadar merkuri dilakukan di UPT Balai Laboratorium Kesehatan Provinsi Sumatera Barat menggunakan Spektrofotometer Serapan Atom GBC 9322AA. Hasil pemeriksaan kadar merkuri menunjukkan hanya satu sampel yang mengandung merkuri dari 15 sampel yang diperiksa. Satu sampel ini masih dalam batas aman berdasarkan Permenkes No.492/2010. Simpulan penelitian ini adalah semua air minum isi ulang di Kelurahan Jati aman untuk dikonsumsi berdasarkan kadar merkuri.
\end{abstract}

Kata kunci: merkuri, DAMIU, Padang

\begin{abstract}
According to Health Ministry Regulations No. 492/2010 about the quality requirements of drinking water, mercury is a chemical that is related to health, so maximum allowable is $0,001000 \mathrm{mg} / \mathrm{L}$. Mercury becomes dangerous if it's level beyond 0,001000 mg/L. The objective of this study was to identify the levels of mercury in refill drinking water samples in Jati, Padang. This study used descriptive method with sampling technique was total sampling Population in this researh was all of refill drinking water location in Jati. This research was held from August 2017 until February 2018. The determination of mercury consentration conducted at UPT Health Laboratory of West Sumatera Province and use Atomic Absorption Spectophotometer (AAS) GBC 9322AA. Examination results of mercury concentration is only one sample from 15 samples consist of mercury, but the consentration still in within the limits allowed by Health Ministry Regulations No. 492/2010. The conclusion of this study is all drinking water refill in Jati safe for consumption based on mercury levels.
\end{abstract}

Keywords: mercury, refill drinking water, Padang

Affiliasi penulis: 1. Prodi Kedokteran Fakultas Kedokteran Universitas Andalas Padang (FK Unand), 2. Bagian Fisika FK Unand, 3. Bagian Biokimia FK Unand

Korespondensi: Kirbi Vira Akesa, Email: kirbivira@gmail.com Telp: 081277643777

\section{PENDAHULUAN}

Air merupakan senyawa kimia yang sangat penting bagi kehidupan di bumi ini karena air merupakan kebutuhan pokok makhluk hidup untuk melakukan berbagai aktivitas. Manfaat air bagi kehidupan tidak dapat digantikan oleh senyawa lain. Fungsi air adalah digunakan untuk berbagai keperluan seperti untuk minum, keperluan rumah tangga, keperluan industri, pertanian, pembangkit tenaga listrik, untuk sanitasi dan untuk transportasi baik di sungai maupun laut. ${ }^{1}$

Pada era sekarang pemenuhan kebutuhan air minum masyarakat sangat bervariasi. Ada masyarakat 
yang mengambil air minum dari mata air, air sungai, air tanah, baik menggunakan sumur dangkal ataupun dalam. Ada juga dari air perpipaan yang diproduksi oleh Perusahaan Daerah Air Minum (PDAM) setempat, tetapi air ini harus dimasak terlebih dahulu sebelum dikonsumsi. Di kota besar, dalam hal pemenuhan kebutuhan air minum masyarakat juga mengkonsumsi Air Minum Dalam Kemasan (AMDK), karena praktis dan dianggap lebih higienis. AMDK diproduksi oleh industri melalui proses otomatis dan disertai dengan pengujian kualitas sebelum diedarkan ke masyarakat. Akan tetapi lama kelamaan masyarakat merasa bahwa AMDK semakin mahal, sehingga muncul alternatif lain yaitu air minum yang diproduksi oleh Depot Air Minum Isi Ulang (DAMIU). Depot air minum isi ulang adalah usaha industri yang melakukan proses pengolahan air baku menjadi air minum dan menjual langsung kepada konsumen. $^{2}$

Masyarakat Sumatera Barat pada umumnya menggunakan sumber air minum yang berasal dari DAMIU dengan persentase rata-rata $32,7 \%$. Kota Padang merupakan urutan kedua terbanyak setelah Kota Pariaman yang sumber air minum masyarakat berasal dari DAMIU dengan persentase masingmasing 55,4\% dan 56,1\%. ${ }^{3}$ Jumlah DAMIU yang ada di Kota Padang adalah sebanyak 657 depot dengan jumlah depot terbanyak terdapat di wilayah kerja Kecamatan Koto Tangah yaitu sebanyak 139 depot, disusul Kecamatan Padang Timur 68 depot dan Kecamatan Pauh sebanyak 47 depot. $^{4}$

Disperindag Kota Padang menjelaskan bahwa sebagian besar air baku dari Depot Air Minum Isi Ulang di Kota Padang bersumber dari air permukaan dan air tanah di Kabupaten Solok ${ }^{5}$. Kabupaten Solok merupakan daerah intensif pertanian dan merupakan daerah sentral produksi padi di Sumatra Barat ${ }^{6}$. Daerah pertanian menggunakan pestisida sebagai pelindung dari hama, pada pestisida umumnya terdapat kandungan merkuri. $^{7}$

Air minum dikatakan aman bagi kesehatan manusia apabila memenuhi persyaratan secara fisika, mikrobiologi, kimia dan radioaktif. Persyaratan kualitas air minum ini telah ditetapkan oleh pemerintah dalam Permenkes RI No. 492/MENKES/PER/IV/2010 tentang persyaratan kualitas air minum. Parameter wajib yang berhubungan langsung dengan kesehatan manusia salah satunya adalah kandungan kimia anorganik dalam air minum. Beberapa zat kimia yang termasuk dalam parameter tersebut antara lain merkuri $(\mathrm{Hg})$, arsen (As), fluorida (F), kromium (Cr), kadmium (Cd), nitrit $\left(\mathrm{NO}_{2}{ }^{-}\right)$, nitrat $\left(\mathrm{NO}_{3}{ }^{-}\right)$, sianida $(\mathrm{CN})$ dan selenium (Se). Berdasarkan parameter logam berat pada air minum tersebut yang memiliki sifat sangat toksik bagi tubuh manusia adalah merkuri $(\mathrm{Hg})$ dan karena dapat menyebabkan efek teratogenik jika di konsumsi dalam waktu yang lama. Menurut Peraturan Menteri Kesehatan Nomor 492/MENKES/PER/IV/2010 tentang syarat-syarat dan pengawasan kualiatas air, kadar merkuri $(\mathrm{Hg})$ dalam air minum tidak boleh lebih dari $0,001000 \mathrm{mg} / \mathrm{L}^{8}$

Merkuri yang terdapat di perairan disebabkan oleh dua hal. Pertama; oleh kegiatan perindustrian seperti pabrik cat, kertas, peralatan listrik, chlorine dan proses pembuatan obat-obatan yang digunakan oleh manusia serta sebagai bahan pembuatan alkil merkuri untuk insektisida pada pertanian. Kedua; oleh alam itu sendiri melalui proses pelapukan batuan dan peletusan gunung berapi. ${ }^{7,9}$ Merkuri yang dihasilkan oleh kegiatan industri dan proses penambangan yang terendapkan pada permukaan tanah, mengakibatkan masuknya polusi merkuri ke dalam tanah dan masuk ke dalam lingkungan air tanah melalui celah-celah yang dibawa oleh air hujan yang masuk ke dalam tanah. Logam merkuri mudah masuk ke dalam tanah karena logam merkuri memiliki sifat mudah mengkristal, sehingga pada saat terjadi pengkristalan dapat menyebabkan merkuri terakumulasi di dalam tanah dan akan mencemari air tanah. ${ }^{10}$

Semua komponen merkuri baik dalam bentuk metal dan bentuk alkil yang masuk ke dalam tubuh manusia secara terus menerus akan menyebabkan kerusakan permanen pada otak, hati dan ginjal. Efek toksisitas merkuri pada manusia tergantung pada bentuk komposisi merkuri, jalan masuknya kedalam tubuh dan lamanya berkembang. ${ }^{7}$

Merkuri juga dapat mencemari air pegunungan terutama pada gunung vulkanik. Secara kimia, material erupsi mengandung berbagai unsur baik memiliki manfaat dalam menambah zat hara, juga mengandung logam berat berbahaya bagi manusia. Di Jawa Tengah 
terdapat merkuri pada air panas pegunungan meski dalam konsentrasi yang relatif rendah. ${ }^{11}$

Menurut hasil sensus penduduk pada tahun 2016, jumlah penduduk di Kota Padang adalah sebanyak 914.968 orang. Penduduk di Kecamatan Padang Timur sebanyak 85.473 orang yang merupakan kecamatan dengan tingkat kepadatan penduduk tertinggi yaitu sebanyak 10.487 orang per $\mathrm{km}^{2}$. Salah satu kelurahan di Kecamatan Padang Timur adalah Kelurahan Jati yang memiliki jumlah penduduk sebanyak 9.717 jiwa. $^{12}$

Hasil wawancara dengan beberapa anggota rumah tangga di Kelurahan Jati didapatkan 37 orang dari 50 orang menggunakan Air Minum Isi Ulang (AMIU) sebagai sumber air minum. Wawancara juga telah dilakukan terhadap 15 pemilik DAMIU di kelurahan Jati tentang sumber air yang digunakan. Hasilnya adalah semua AMIU berasal dari Gunung Talang, Kabupaten Solok. Sumber air yang berasal dari gunung talang tersebut diperoleh dari sungai yang terdapat disekitar gunung atau tempat penampungan air yang berasal dari mata air. Apakah sumber air yang digunakan oleh pemilik DAMIU tersebut tercemar oleh merkuri, baik oleh limbah pertanian atau dari erupsi lahar gunung itu belum ada laporan yang peneliti temui? Oleh karena itu perlu diteliti apakah DAMIU yang terdapat di Kelurahan Jati tercemar dengan merkuri?

Peneltian ini dilakukan dengan tujuan untuk mengidentifikasi kadar merkuri pada Air Minum Isi Ulang (AMIU) yang diproduksi oleh DAMIU di Kelurahan Jati, Kota Padang dan distribusi frekuensi AMIU yang sesuai dengan persyaratan kualitas air minum menurut peraturan mentri kesehatan nomor 492/MENKES/PER/IV/2010 berdasarkan kandungan merkuri.

\section{METODE}

Penelitian ini bersifat deskriptif yang dilakukan

di UPT Balai Laboratorium Kesehatan Provinsi Sumatera Barat dari Juli 2017 sampai Februari 2018. Sampel pada penelitian ini adalah air minum dari seluruh depot air minum isi ulang di Kelurahan Jati sebanyak 15 depot. Observasi lokasi depot air minum isi ulang dan pengambilan sampel air dilakukan di
Kelurahan Jati Padang. Air yang menjadi sampel adalah air yang sudah menjalani proses produksi dan siap untuk dikonsumsi. Pemeriksaan kadar merkuri terhadap sampel air dilakukan di UPT Balai Laboratorium Kesehatan Provinsi Sumatera Barat. Pemeriksaan sampel sesuai dengan SNI 19-6964.22003 tetang cara uji merkuri pada air secara spektrofotometri dengan SSA GBC 9322AA. ${ }^{13}$

HASIL

\section{Kandungan Merkuri pada Sampel}

Hasil penetapan kadar merkuri dari semua sampel disajikan pada Tabel 1.

Tabel 1. Kandungan Fluorida pada Sampel

\begin{tabular}{ccc}
\hline No & $\begin{array}{c}\text { Nama } \\
\text { Kode } \\
\text { Sampel }\end{array}$ & $\begin{array}{c}\text { Konsentrasi } \\
\text { Merkuri (mg/L) }\end{array}$ \\
\hline 1 & L0206 & 0,000000 \\
2 & L0207 & 0,000000 \\
3 & L0208 & 0,000000 \\
4 & L0209 & 0,000000 \\
5 & L0210 & 0,000000 \\
6 & L0211 & 0,000000 \\
7 & L0212 & 0,000021 \\
8 & L0213 & 0,000000 \\
9 & L0214 & 0,000000 \\
10 & L0215 & 0,000000 \\
11 & $L 0216$ & 0,000000 \\
12 & L0217 & 0,000000 \\
13 & L0218 & 0,000000 \\
14 & L0219 & 0,000000 \\
15 & L0220 & 0,000000 \\
\hline
\end{tabular}

Pada Tabel 1 didapatkan bahwa meskipun terdapat 1 sampel yang positif mengandung merkuri, namun masih memenuhi pesyaratan kualitas air minum berdasarkan peraturan mentri kesehatan nomor 492/MENKES/PER/IV/2010. ${ }^{8}$

Tabel 2. Distribusi Frekuensi AMIU yang memenuhi persyaratan Permenkes No.492/2010

\begin{tabular}{llc}
\hline \multicolumn{1}{c}{$\begin{array}{c}\text { Persyaratan } \mathbf{H g} \leq \mathbf{0 , 0 0 1} \\
(\mathbf{m g} / \mathbf{L})\end{array}$} & Frekuensi Persentase \\
\hline Memenuhi & 15 & $100 \%$ \\
Tidak memenuhi & 0 & $0 \%$ \\
\hline
\end{tabular}


Berdasarkan Tabel 2 bisa dilihat bahwa seluruh depot air minum yang berada di Kelurahan Jati sebanyak 15 buah tersebut sesuai dengan Permenkes No 492 tahun $2010 .^{8}$

\section{PEMBAHASAN}

Hasil penelitian ini menunjukkan bahwa kadar merkuri pada air minum yang berasal dari depot air minum di kelurahan Jati berkisar antara 0,000000 sampai $0,000021 \mathrm{mg} / \mathrm{L}$. Hal ini menunjukkan bahwa kandungan merkuri pada air minum isi ulang yang dijual di DAMIU di Kelurahan Jati masih sesuai dengan Permenkes No.492 tahun 2010. Seluruh sumber air minum isi ulang yang dijual pada DAMIU di Kelurahan Jati berasal dari Gunung Talang Kabupaten Solok. Hasil penelitian ini hampir sama dengan penelitian pada air minum isi ulang di Jakarta, Tangerang dan Bekasi tahun 2003 dimana didapatkan kadar merkuri pada air minum tersebut $<0,001000 \mathrm{mg} / \mathrm{L} .{ }^{14}$ Penelitian ini juga memiliki hasil yang hampir sama dengan penelitian di Kabupaten Bombana, Sulawesi Tenggara dimana kadar merkuri pada air minum isi ulangnya adalah $0,0005 \mathrm{mg} / \mathrm{L}^{15}$

Pada Tabel1 menunjukkan hanya satu depot di Kelurahan Jati yang mengandung merkuri, dengan kadar 0,000021 mg/L. Kadar merkuri sebesar $0,000021 \mathrm{mg} / \mathrm{L}$ masih dikategorikan aman bagi kesehatan jika dikonsumsi setiap harinya sebanyak 2 liter (jumlah merkuri yang dikonsumsi 0,000042 $\mathrm{mg} / \mathrm{L} /$ hari). Kadar merkuri tersebut masih jauh dari batas maksimum yang ditetapkan oleh Permenkes No. 492/2010 yaitu $\leq 0,001000 \mathrm{mg} / \mathrm{L}^{8}$

Penelitian ini menunjukkan bahwa masyarakat Jati yang mengonsumsi air minum yang berasal dari depot masih jauh dari risiko efek keracunan kronis merkuri karena kadar merkuri yang terdapat pada air minum isi ulang di Kelurahan Jati masih jauh dari batas maksimum yang telah ditetapkan.

Apabila seseorang terpapar merkuri lebih dari $300 \mathrm{mg} /$ hari maka seseorang tersebut akan mengalami keracunan merkuri. Merkuri dapat menyerang berbagai organ dalam tubuh tetapi target organ yang paling diserang oleh merkuri adalah, otak, ginjal, hati dan saluran cerna. ${ }^{16}$
Metilmerkuri menyerang susunan saraf pusat dengan target organ utama adalah otak. Lesi pada cerebellum berakibat pada hilang keseimbangan (ataxia) dan gangguan bicara (dysarthria). Gangguan penglihatan terjadi pada penyempitan bidang padang, kesulitan penglihatan pada daerah tepi akibat dari kerusakan di daearah occipital lobe. Gangguan sensasi atau stereo anesthesia terjadi karena kerusakan pada postcentral gyrus. Kelemahan otot, kram atau gangguan pergerakan merupakan tanda dari kerusakan pada precentral gyrus. Kesulitan pendengaran disebabkan adanya gangguan pada daerah temporal transverse gyrus. Keluhan pada kesulitan dan gangguan indera perasa baik rasa nyeri, sentuhan ataupun suhu akibat adanya gangguan pada saraf sensorik. ${ }^{17}$

\section{SIMPULAN}

Semua DAMIU di Kelurahan Jati, Kota Padang memenuhi persyaratan kualitas air minum menurut peraturan mentri kesehatan nomor 492/MENKES/PER/IV/2010 berdasarkan kandungan merkuri.

\section{DAFTAR PUSTAKA}

1. Wisnu AW. Dampak pencemaran lingkungan. Yogyakarta: Penerbit Andi; 2001.

2. Haryono. Kandungan bakteri total Coli dan Eschericia coli / fecal coli air minum dari depot air minum isi ulang di Jakarta, Tangerang dan Bekasi. Buletin Penelitian Kesehatan. 2004;32(4):134-5.

3. Kementerian Kesehatan RI Riskesdas dalam angka Provinsi Sumatera Barat. Jakarta: Lembaga Penerbitan Badan Litbangkes. 2013.

4. Dinas Kesehatan Sumatera Barat. Profil kesehatan Sumatera Barat. Padang: Dinas Kesehatan Sumatera Barat; 2016.

5. Disperindag Kota Padang. Persyaratan teknis depot air minum isi ulang dan perdagangannya. Jakarta: Perindag RI: 2011.

6. Badan Perencanaan Pembangunan Daerah Kota Solok (BAPPEDA Kota Solok). Kota Solok dalam angka 2014. Solok: BAPPEDA Kota Solok; 2014. 
7. Alfian Z. Merkuri: Antara manfaat dan efek penggunaanya bagi kesehatan manusia dan lingkungannya (skripsi). Medan: Fakultas MIPA Universitas Sumatera Utara; 2006.

8. Depkes RI. Permenkes RI No. 492/MENKES/PER/ IV/2010. Tentang persyaratan kualitas air minum. Jakarta : Depkes RI.2010.

9. Budiono A. Pengaruh pencemaran merkuri terhadap biota air. Bogor: IPB; 2003.

10. US Department Of Health \& Human Services. Mercury toxicity. US Department Of Health \& Human Services;1992.

11. Anggraini R. Kandungan logam air sumur dan air PDAM dengan sistem pendeteksi kelayakan air minum (Elektrolizer Air) di Kecamatan Sumber Sari (skripsi). Jember: Bagian Ilmu Kesehatan Gigi Masyarakat Fakultas Kedokteran Gigi Universitas Jember; 2012.

12. Badan Pusat Statistik (BPS). Sensus penduduk Kota Padang. BPS; 2016.
13. Badan Standardisasi Nasional. Metode pengujian kadar merkuri dalam air dengan alat spektrofotometri serapan atom secara atomisasi dingin. Badan Standardisasi Nasional. SNI 196964.2-2003.

14. Athena. Kandungan $\mathrm{Pb}, \mathrm{Cd}, \mathrm{Hg}$ dalam air minum dari depot air minum isi ulang di Jakarta, Tangerang dan Bekasi. Buletin Ekologi Kesehatan. 2004;(3)3:150.

15. Ditjen P2P Kementrian Kesehatan RI Makassar. Laporan kinerja balai teknik kesehatan lingkungan dan pengendalian penyakit Makassar. Makassar: DitjenP2P; 2017.

16. Suprijanto I. Kandungan logam berat sumber air minum di DKI Jakarta. Buletin Penelitian Kesehatan. 1988;(16) 2: 22-4.

17. Yanuar A. Toksisitas merkuri disekitar kita. Departemen Farmasi FMIPA-Universitas Indonesia. 2008. 